\title{
Effect of ZnO Nanoparticles Coating Layers on Top of ZnO Nanowires for Morphological, Optical, and Photovoltaic Properties of Dye-Sensitized Solar Cells
}

\author{
Muhammad Saleem ${ }^{1}$, W. A. Farooq ${ }^{2, *}$, M. I. Khan ${ }^{3}$, Majid. Niaz. Akhtar ${ }^{4}{ }^{\oplus}$, Saif Ur Rehman ${ }^{5}$, \\ Naseeb Ahmad ${ }^{1}$, Muhammad Khalid ${ }^{6}$, M. Atif ${ }^{2}$, Mona A. AlMutairi ${ }^{2}$ and Muhammad Irfan ${ }^{7}$ \\ 1 Department of Physics, Khwaja Freed University of Engineering and Information Technology, Rahim Yar \\ Khan 64200, Pakistan; saleem.malikape@gmail.com (M.S.); ptckhan3@gmail.com (N.A.) \\ 2 Department of Physics and Astronomy, College of Science, King Saud University, Riyadh 11451, Saudi \\ Arabia; atifphy@gmail.com (M.A.); monaalmutairi@gmail.com (M.A.A.) \\ 3 Department of Physics, The University of Lahore, Lahore 53700, Pakistan; iftikharphysicsuet@gmail.com \\ 4 Department of Physics, Muhammad Nawaz Sharif (MNS) University of Engineering and Technology, \\ Multan 60000, Pakistan; majidniazakhtar@gmail.com \\ 5 Department of Physics, COMSATS University Islamabad, Lahore 54000, Pakistan; saifuetian@gmail.com \\ 6 Department of Chemistry, Khwaja Fareed University of Engineering and Information Technology, Rahim Yar \\ Khan 64200, Pakistan; muhammad.khalid@kfueit.edu.pk \\ 7 CAS Key Laboratory of Strongly Coupled Quantum Matter Physics, USTC, Hefei 230026, China; \\ awazirzada@ksu.edu.sa \\ * Correspondence: wafarooq@hotmail.com
}

Received: 25 August 2019; Accepted: 20 November 2019; Published: 26 November 2019

\begin{abstract}
This paper reports on the synthesis of $\mathrm{ZnO}$ nanowires (NWs), as well asthe compound nanostructures of nanoparticles (NPs) and nanowires (NWs+NPs) with different coating layers of NPs on the top of NWs and their integration in dye-sensitized solar cells (DSSCs). In compound nanostructures, NWs offer direct electrical pathways for fast electron transfer, and the NPs of $\mathrm{ZnOdispread}$ and fill the interstices between the NWs of $\mathrm{ZnO}$, offering a huge surface area for enough dye anchoring and promoting light harvesting. A significant photocurrent density of $2.64 \mathrm{~mA} / \mathrm{cm}^{2}$ and energy conversion efficiency of $1.43 \%$ was obtained with NWs-based DSSCs. The total solar-to-electric energy conversion efficiency of the NWs+a single layer of NPs was found to be $2.28 \%$, with a short-circuit photocurrent density $\left(J_{S C}\right)$ of $3.02 \mathrm{~mA} / \mathrm{cm}^{2}$, open-circuit voltage $\left(V_{\mathrm{OC}}\right)$ of $0.74 \mathrm{~V}$, and a fill factor (FF) of 0.76 , which is $60 \%$ higher than that of NWs cells and over $165 \%$ higher than NWs+a triple layer of NPs-based DSSCs. The improved performance was obtained due to the increased specific surface area for higher dye anchoring and light harvesting of compound nanostructures with NWs+a single layer of NPs.
\end{abstract}

Keywords: DSSCs; coating layers of NPs; nanowires

\section{Introduction}

Dye-sensitized solar cells (DSSCs) are considered promising devices for energy harvesting and large-scale fabrication due to their relatively high efficiency, costeffectiveness, and simple preparation process $[1,2]$. Many types of photovoltaic devices have been inducted in the market during the last 50 years [3-5]. However, their large-scale utility is still limited due to some challenges related to their stability, durability, the number of interparticle hops, and the low surface area [6-8]. So for, many $\mathrm{ZnO}$ photoanode architectures such as nanowires [9-11], nanobelts [12,13], nanoparticles [14-16], and nanotubes $[10,17,18]$ have been fabricated for DSSCs. Recently, one-dimensional (1D) ZnO 
nanostructures have been extensively studied, which have the capacity to provide a direct pathway and less trapping sites than the random network for the fast collection of photogenerated electrons, and thereby reduce the number of interparticle hops [19-23]. However, such 1D nanostructures seem to have insufficient surface area, which constrains solar-to-electric energy conversion efficiency to a relatively low level compared to $\mathrm{TiO}_{2}$ nanostructures. Therefore, one way to further boost the efficiency of a cell is to pull off the light-harvesting ability of the photoelectrode film. One effective way to overcome these problems is either by utilizing optical enhancement effects, which can be achieved by mixing NPs with ZnO NWs, or by using a nanospheres film instead of a nanoparticles film. In several studies, different fractions (mass ratio) of $\mathrm{NPs}$ of $\mathrm{ZnO} / \mathrm{TiO}_{2}$ were mixed with $\mathrm{ZnO} / \mathrm{TiO}_{2}$ nanowires, nanorods, and nanofibers for affording a rapid electron conduction pathway and enlarging a dye adsorption area for increasing cell performance [24-29]. However, for significant enhancement in the overall performance of the cell, we still need an increase in the surface area of nanowire arrays [30].

Herein, we have made the use of $\mathrm{ZnO}$ nanowires (NWs) and compound nanostructures of $\mathrm{ZnO}$ nanowires and nanoparticles (NWs + NPs) with different coating layers of NPs on top of NWs as the photoelectrodes in DSSCs. The key point of this study is the coating of single, double, and triple layers of NPs and to study the effect of the coating layers' thickness on the morphological, optical and photovoltaic properties of DSSCs. To enhance the performance of ZnO NWs DSSCs, nanoparticles of $\mathrm{ZnO}$ were filled in the interstices of NWs to achieve a fast electron transport pathway and to enlarge the dye adsorption area. Surprisingly, it is noted that DSSCs fabricated with double and triple layer coatingsof NPs show worse performance than those of NWs/NWs with a single layer of NPs. This can be due to the increased thickness, as an overly thick film aggravates unnecessary charge recombination and poses more constraint on mass transfer. Thus, we can infer that the appropriate content of NP incorporation into the NWs can promote the dye adsorption, transport the electrons, decrease the charge recombination, and thereby increase the performance of the cells.

\section{Experimental}

\subsection{Synthesis of $\mathrm{ZnO}$ Nanoparticles}

$\mathrm{NPs}$ of $\mathrm{ZnO}$ were synthesized by dissolving $2.96 \mathrm{~g}$ of zinc acetate dihydrate $\left(\mathrm{Zn}\left(\mathrm{CH}_{3} \mathrm{COO}\right)_{2} .2 \mathrm{H}_{2} \mathrm{O}\right.$, Merck, Kenilworth, NJ, USA) (ZAD) in $150 \mathrm{~mL}$ of diethylene glycol $\left(\mathrm{C}_{4} \mathrm{H}_{10} \mathrm{O}_{3}\right.$, Merck, Kenilworth, NJ, USA) (DEG) in a conical flask. The synthesis was performed in the following steps:(i) prepare the solution, (ii) heat it for hydrolysis, and (iii) heat treatment of the final samples. The experimental flask was fitted with a thermometer (Figure 1) and placed on hot stirrer, under continuous stirring. The heating of solution was carried out to $500{ }^{\circ} \mathrm{C}$ at a rate of $6{ }^{\circ} \mathrm{C} / \mathrm{min}$. When the temperature of the clear solution reached $180^{\circ} \mathrm{C}$, the solution first turned yellow and then into a milky white color. The temperature of the solution was fixed at $180{ }^{\circ} \mathrm{C}$ for $15 \mathrm{~min}$ and then stopped heating. When the reaction stopped and the temperature of the solution reached $26^{\circ} \mathrm{C}$, the white precipitate was collected by centrifuge and washed three times with ethanol. The powder was placed in a furnace at $400{ }^{\circ} \mathrm{C}$ for 1h to remove extra residual organics. 


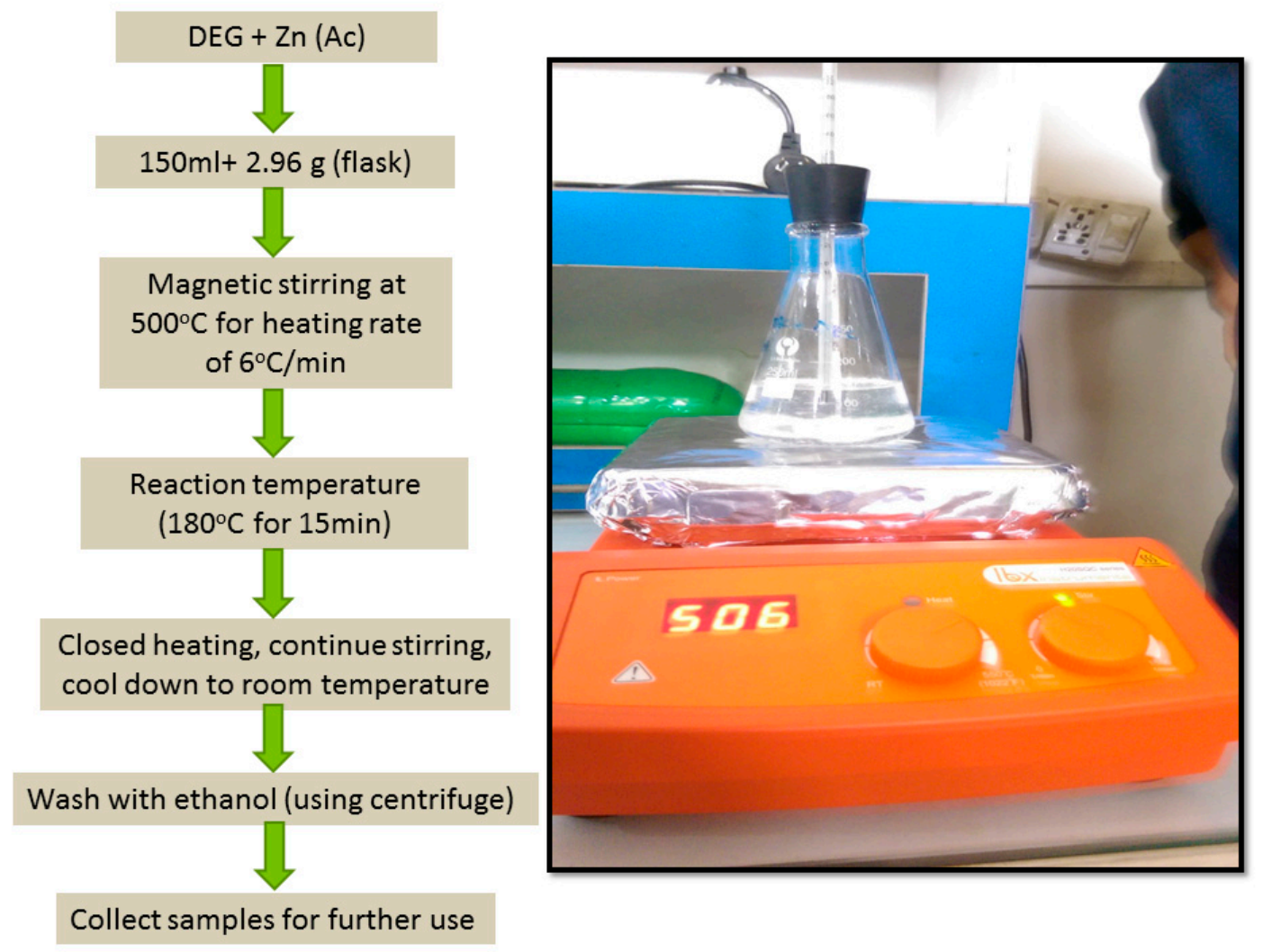

Figure 1. Procedure of the experiment.

\subsection{ZnO Nanowire Arraysand Nanoparticle Compound Structures Synthesis}

$\mathrm{ZnO}$ NWs arrays were synthesized in an aqueous solution, using a two-step process described elsewhere [31]. NWs were grown by immersing the seeded FTO substrates vertically in glass bottles containing $55 \mathrm{~mL}$ of solution. The growth solution consists of $1.09 \mathrm{~g}$ of zinc nitrate hexahydrate $(\mathrm{ZNH})$, $0.70 \mathrm{~g}$ hexamethylenetetramine (HMTA), and $0.4 \mathrm{M}$ ammonium hydroxide $\left(\mathrm{NH}_{4} \mathrm{OH}\right)$. Then, the bottles were covered and placed in an electric oven at $95{ }^{\circ} \mathrm{C}$ for $4 \mathrm{~h}$. After growth, the substrates were immediately washed with distilled water. Finally, the NWs grown on substrates were backed at $450{ }^{\circ} \mathrm{C}$ for $30 \mathrm{~min}$ to remove excess solvent. The samples were prepared using spincoating. The concentration of $\mathrm{ZnO}$ nanoparticles synthesized in DEG at $500{ }^{\circ} \mathrm{C}$ at a rate of $6{ }^{\circ} \mathrm{C} / \mathrm{min}$ ) was $0.2 \mathrm{~g}$ in $30 \mathrm{~mL}$ of acetone. One sample consist only nanowires (NWs), the second sample was composed of nanowires and a single layer of nanoparticles (NWs+single layer of NPs), the third sample was composed of NWs and a double layer of NPs(NWs+double layer of NPs), and the fourth sample was composed of NWs and three layers of NPs (NWs+triple layer of NPs), as shown in Figure 2.The speed of the spin coater for the grown $\mathrm{ZnO}$ NPs onto NWs was $2500 \mathrm{rpm}$ for $30 \mathrm{~s}$. After each spincoating, the films were placed into a furnace for heating at $200{ }^{\circ} \mathrm{C}$ for $10 \mathrm{~min}$ to evaporate the solvent. This procedure of spinning to preheating was repeated three times for the sample having a triple layer of NWs+NPs. 

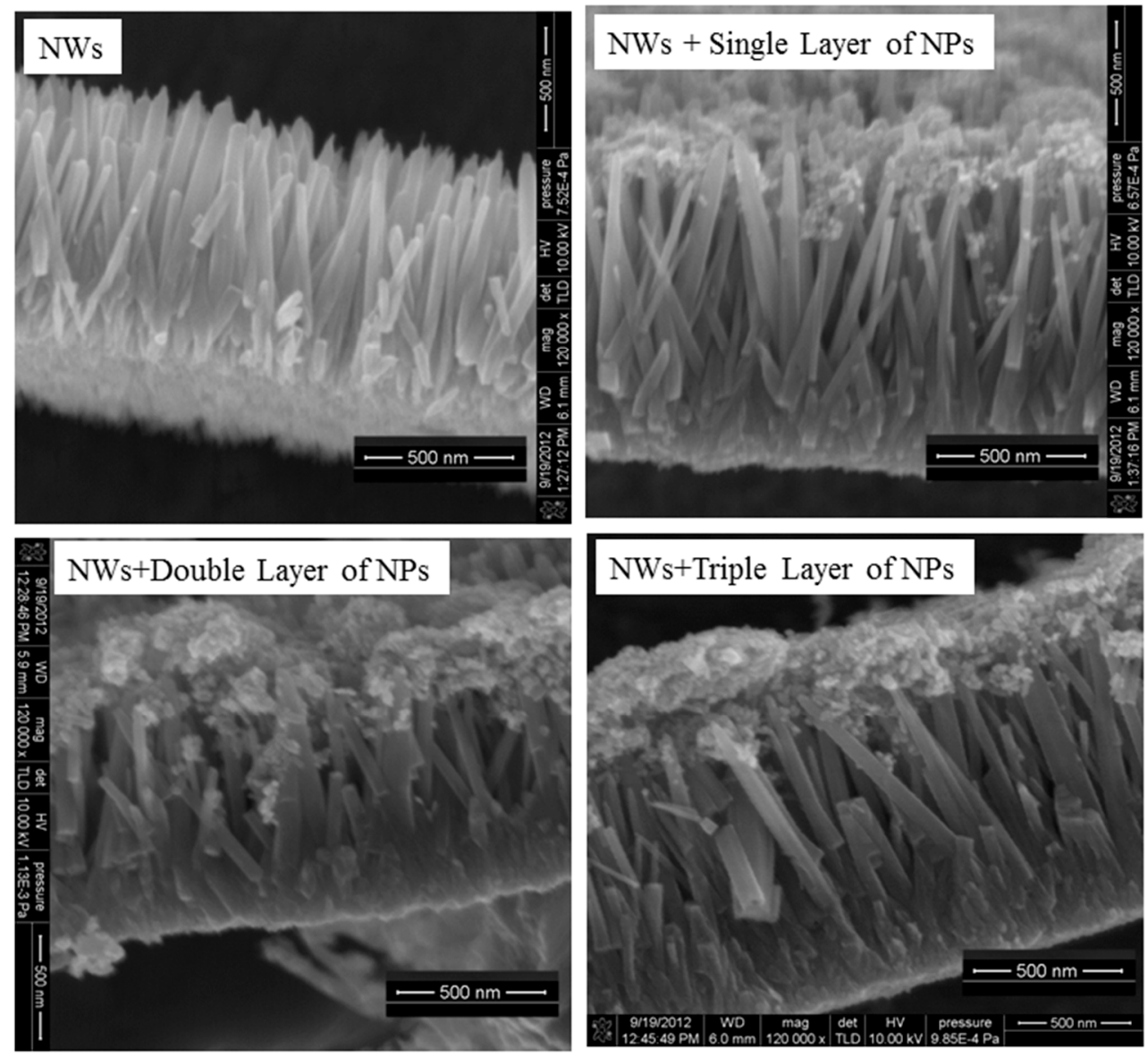

Figure 2. SEM images of the $\mathrm{ZnO}$ nanoproducts.

\subsection{Measurements and Characterizations}

XRD patterns were measured by X-ray diffraction (XRD, Bruker D2 Phaser, Beerlika, MA, USA) using a $2 \theta$ scan. A scanning electron microscope study was done by SEM (model: JEOL JSM-7600F, Tokyo, Japan). I-V measurements of DSSCs were taken out with a Keithley 2400 source meter under an AM 1.5 global air mass filter, and the voltage sweep rate was $0.01 \mathrm{~V} / \mathrm{s}$. The optical properties after dye loading were examined using a Perkenelmer Lambda-750 UV-VIS NIR spectrophotometer.

\subsection{Cell Assembly}

The effective area of photoelectrodes was $0.5 \mathrm{~cm} \times 0.5 \mathrm{~cm}=0.25 \mathrm{~cm}^{2}$. Dyeing was carried out by dipping these films in solutions of N719 dye for $3 \mathrm{~h}$, and the films were then removed from the dye solution. The dyed films were rinsed off with acetonitrile to remove an excess of N719 dye remaining on the surface of the films. The dye was prepared by $0.5 \mathrm{mMof}$ ditertbutylpyridylcis-bis" (4,4'-dicarboxy-2,2'-bipyridine)dithiocyanato ruthenium(II)", in a 1:1 mixture of acetonitrile. After dyeing, DSSCs were assembled by placing Pt-coated $\left(8 \Omega \cdot \mathrm{cm}^{-1}\right)$ counter electrodes on prepared photoelectrodes separated by $30 \mu \mathrm{m}$ of hot-melt surlyn film. The iodide/tri-iodide electrolyte consisting of $0.05 \mathrm{MI}_{2}$ and $0.5 \mathrm{M}$ 1,2-dimethyl-3-propylimidazolium iodide in acetonitrile was filed between the space of each cell by capillary action. Finally, three cells of each sample were fabricated and tested to check the reproducibility and almost similar results of I-V measurement happened. 


\section{Results and Discussion}

\subsection{Structural Analysis}

Figure 3 depicts the crystalline orientation of the ZnO NWs, NWs+a single layer of NPs, NWs+a double layer of NPs, and NWs+a triple layer of NPs compound structures determined by XRD. The XRD peaks of all the structures correspond to $2 \theta=31.7^{\circ}(100), 34.4^{\circ}(002)$, $36.5^{\circ}(101), 47.7^{\circ}(102), 56.8^{\circ}(110), 63.1^{\circ}(103), 66.5^{\circ}(200), 68.1^{\circ}(112), 69.2^{\circ}$ (201) planes of $\mathrm{ZnO}$. The XRD data also show the wurtzite structure of $\mathrm{ZnO}$. These planes agreed well with the standard reported values (JCPDS file No. 36-1451). There are no diffraction peaks corresponding to impurities such as $\mathrm{Zn}$ and $\mathrm{Zn}(\mathrm{OH})_{2}$. The crystallite size of nanoparticles was calculated for the (101) peak due to high intensity using the Scherrer equation [31]. The calculated size of nanocrystallites was $20 \mathrm{~nm}$. The intensity of peaks increases with the increase in thickness due to the growth of NP layers. All the peaks are slightly shifted toward right with the addition of NPs and the absence of any other peak confirms the high purity of the hexagonal $\mathrm{ZnO}$ phase and the good alignment of the samples. It is noteworthy that the intensity of (101) is strongest among the other reflections.

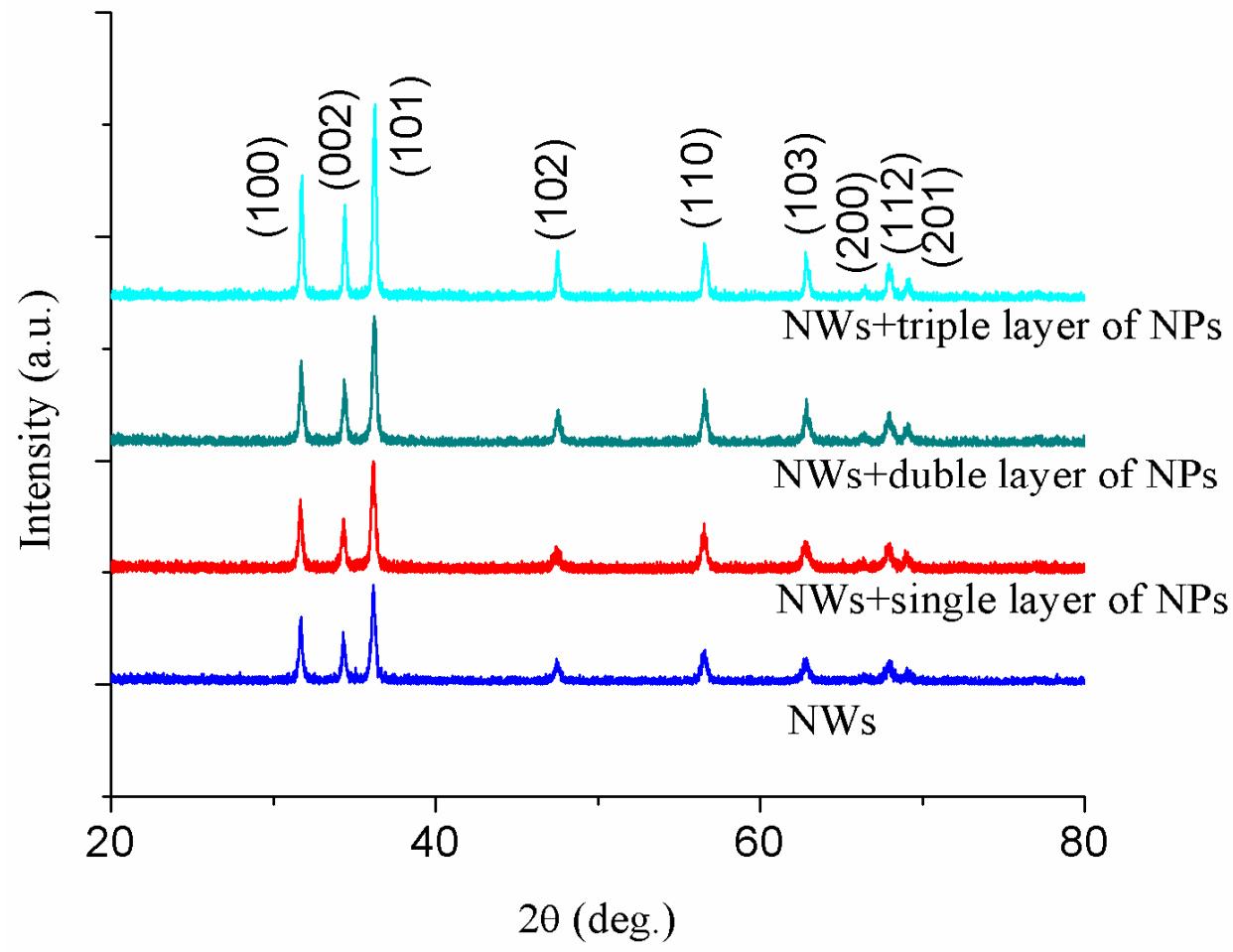

Figure 3. X-ray diffraction(XRD) patterns of the $\mathrm{ZnO}$ nanoproducts.

\subsection{Morphological Analysis}

The crystallographic morphologies of the NWs of ZnO, NWs+a single layer of NPs, NWs+a double layer of NPs, and NWs+a triple layer of NPs were observed using FESEM. From Figure 2, it can be seen that the alignment is good, and the NWs are vertically grown on the substrates (FTO) with a length of about $1.1 \mu \mathrm{m}$. As a result, such a type of one-dimensional nanostructured-based photoelectrode film has insufficient surface area. If the interstitial voids between the NWs might be filled with NPs, the photoelectrodes' surface area would be increased. To overcome this deficiency of surface area, we have spin-coated ZnO NPs on top of NWs. For a single layer of NPs (Figure 2), besides the formation of a topping layer, it can be seen that nearly all of the NPs fill the interstices between the NWs, yielding a combined structure of NWs and NPs. In case of double layers, NPs were detached on top of the NWs. Some NPs were partially penetrated and dispersed between the gaps of nanowires, but a large portion of NPs remained coated on the surface of the nanowire arrays. However, in case 
of triple layers, NPs were sitting on the top of the nanowire arrays without any infiltration between the gaps of NWs except for those that dispersed during the first and second layer. As a result of this infiltration, a thick layer of NPs is built on the surface of NWs (Figure 4, Schematic), which reduces the penetration (diffusion) of electrons from NPs to NWs and increases the trapping/detrapping events. The average thickness of the nanoparticles coating measured by Image J software (Figure 5, Histogram) was 90, 172, and $275 \mathrm{~nm}$ for the single, double, and triple layers, respectively.

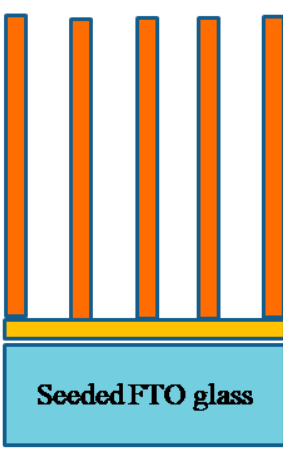

NWs

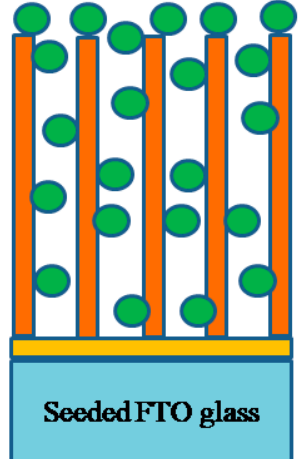

NWs + single layer of NPs

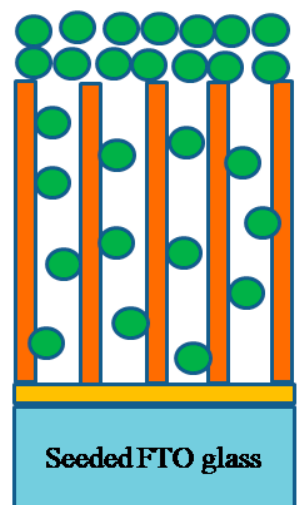

NWs + double layer of NPs

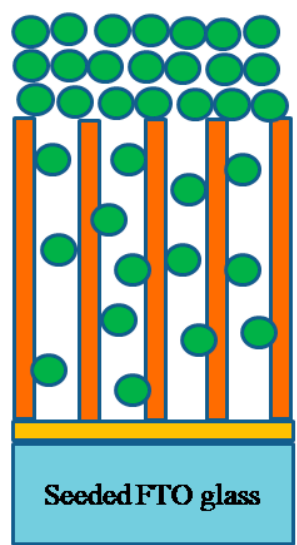

NWs +triple layer of NPs

Figure 4. Schematic representation of photoelectrodes made from nanowires (NWs), NWs+a single layer of nanoparticles(NPs), NWs+a double layer of NPs, and NWs+ atriple layer of NPs.

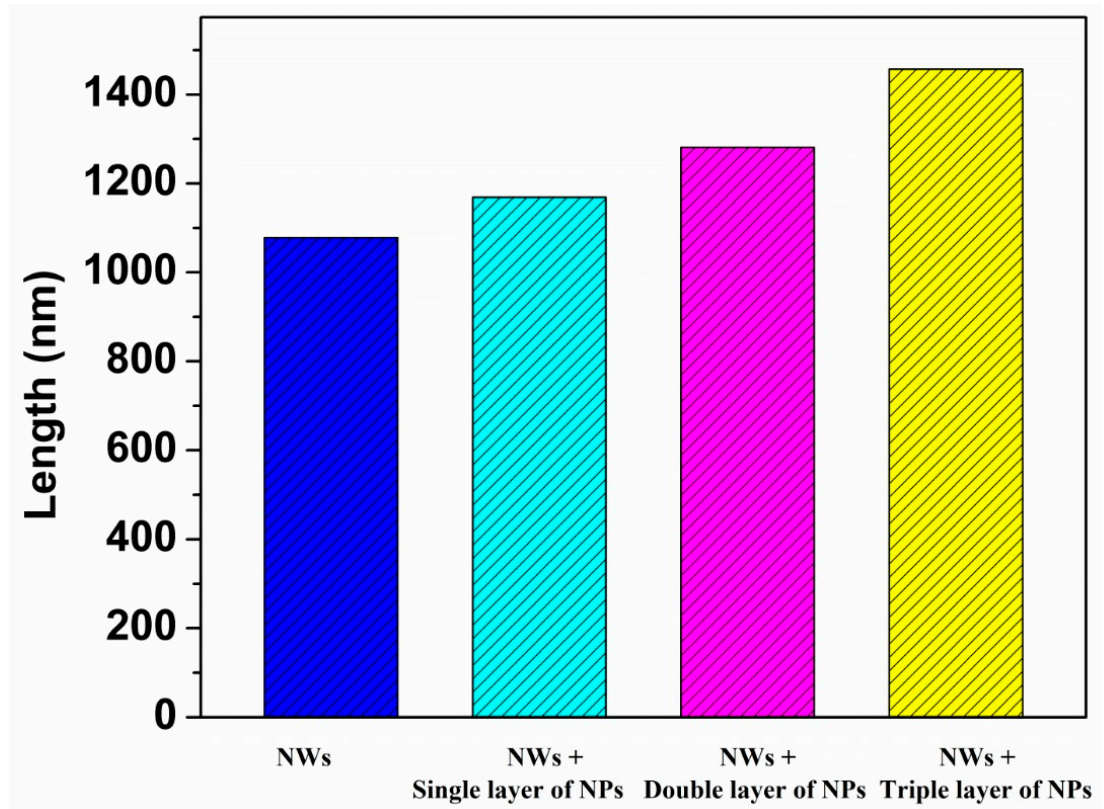

Figure 5. Histogram of increase in length (thickness) with different coating layers.

\subsection{Optical Analysis of Dye/ZnO Anodes}

In Figure 6, the absorption spectra of dye/ZnO NWs, NWs+a single layer of NPs, NWs+a double layer of NPs, and NWs+a triple layer of NPs are shown. It is observed that all the NWs and NWs+NPs electrodes present an absorption peak at $520 \mathrm{~nm}$. These peaks at $520 \mathrm{~nm}$ in all the electrodes are due to a visible $4 \mathrm{~d}-\pi^{*}$ metal-to-ligand charge transfer (MLCT) in N719 dye [32]. Due to the presence of coupling strength between the surface of ZnO NWs and NWs+NPs electrodes and excited dye, these absorption peaks are slightly blue shifted. The different NPs layers on the top of NWs will provide a large surface area for dye loading, and hence improve the light harvesting capability of 
photoelectrodes. It is clear from the absorption spectra (Figure 6) that the dye adsorption capacity of NWs and NWs+NPs films with different layers of NPs is rated in the following order, from high to low: the single layer of a NP compound nanostructure (NWs+a single layer of NPs), nanowires (NWs), a double layer of a NP compound structure (NWs+a double layer of NPs), and a triple layer of a NP compound structure (NWs+a triple layer of NPs). It is evident from the spectra that the single layer of a NP (NWs+a single layer of NPs) compound nanostructure has the highest dye adsorption capacity, because such a configuration contributes more surface area for dye molecules. Hence, as a result, the current density $\left(J_{S C}\right)$ and overall light-to-energy conversion efficiency would increase. The dye adsorption capacity of NWs is less than NWs+a single layer of NPs due to the lower surface area. The other two samples, i.e., NWs+a double layer of NPs and NWs+a triple layer of NPs, show lesser dye adsorption capacity because of the presence of double and triple layers of NPs on the top of the NWs. Since the dye adsorption becomes weaker as the thickness of the layers increases, a thicker layer blocks the complete infiltration of dye into the whole sample. Chang et al. and other researchers proposed that insufficient film thickness leads to a low interfacial surface area, whereas an overly thick film aggravates unnecessary charge recombination and poses more constraint on mass transfer [33-36]. As a result, a photoanode that is too thin or too thick results in lower conversion efficiency. Furthermore, it also causes higher electron transport resistance and increases the recombination of electrons with $I_{3}^{-}$ on the $\mathrm{ZnO}$ surface, resulting in smaller open circuit voltage and efficiency.

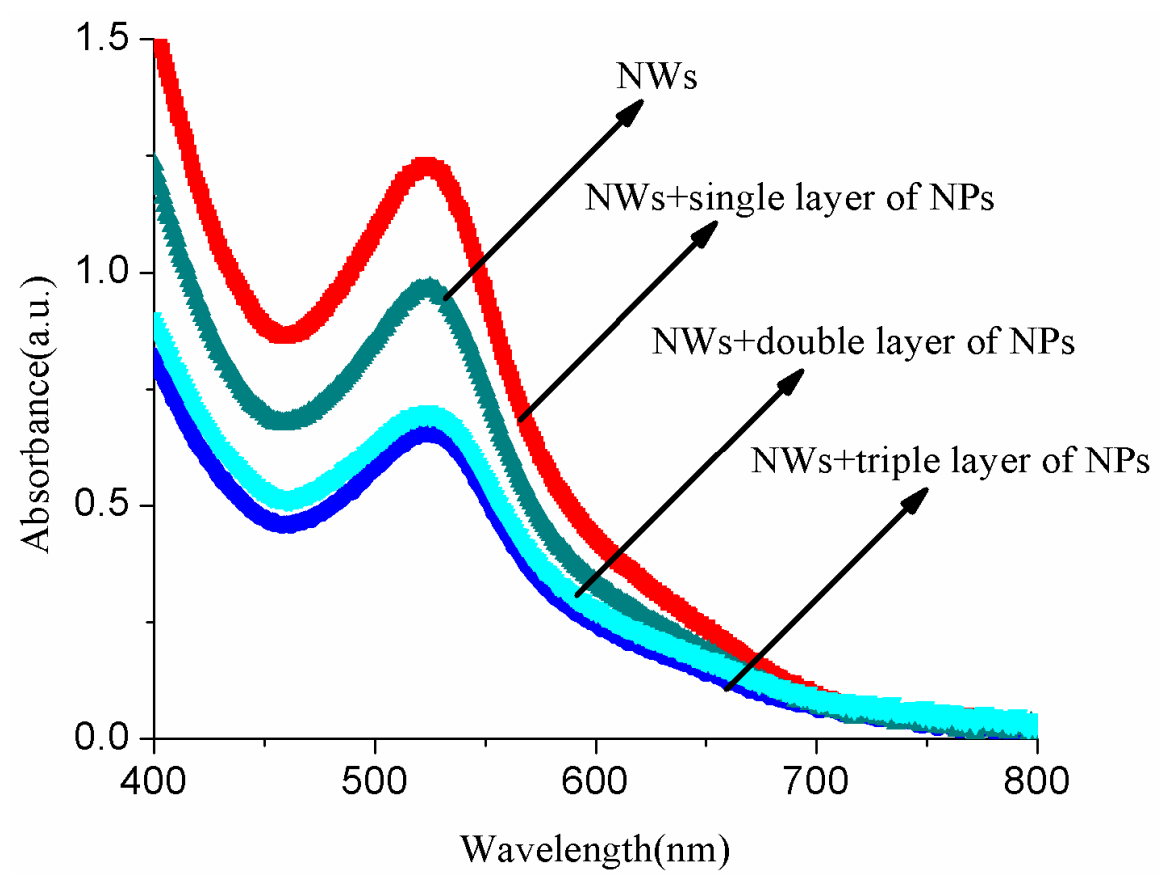

Figure 6. Optical absorbance of N719 dye adsorbed on ZnO compound nanstructures.

\subsection{Current Voltage (I-V) Analysis of DSSCS}

Figure 7 shows the photoelectric characteristics for NWs, NWs+a single layer of NPs, NWs+a double layer of NPs, and NWs+a triple layer of NP compound structure-based solar cells. The parameters measured from I-V curves for thebest cells prepared from different coating layers of NPs on $\mathrm{ZnO}$ nanowires are listed in Table 1. Under illumination, the NWs cell show aJ $J_{\mathrm{SC}}$ of $2.64 \mathrm{~mA} / \mathrm{cm}^{2}$, fill factor (FF) of $0.74, V_{\mathrm{OC}}$ of $0.72 \mathrm{~V}$, and $\eta$ of $1.43 \%$. The NWs photoelectrodes have insufficient internal surface area that results in lower dye loading and lightharvesting $[20,21,37,38]$. The NWs+a single layer of NPs compound structure shows a $J_{\mathrm{SC}}$ of $3.02 \mathrm{~mA} / \mathrm{cm}^{2}, \mathrm{FF}$ of $0.76, V_{\mathrm{OC}}$ of $0.74 \mathrm{~V}$, and $\eta$ of $2.28 \%$. The $J_{\mathrm{SC}}, \eta$, and overall performance obtained from the NWs+a single layer of NPs-based DSSC are substantially increased compared with those of NWs cells alone. The significant enhancement in these results was possibly caused by the superior lightharvesting of the NWs+a single 
layer of NPs DSSC, in which NPs provide the higher specific surface area for more dye anchoring and the NWs provide an effective pathway for rapid electron transport $[27,28,39]$. These results from the NWs and NWs+a single layer of NPs DSSCs closely matched with the results obtained from NWs, NRs, and nanotips [21,24,28,29,40-42], and the results of NWs+a single layer of NPs compound nanostructure show a considerable agreement with the results reported by other researchers listed in Table 2 for comparison [27,43-48]. On the other hand, the other samples of NWs+a double layer of NPs and NWs+a triple layer of NPs show worse performance; i.e., $J_{S C}$ decreases from 3.02 to $2.11 \mathrm{~mA} / \mathrm{cm}^{2}$ and $\eta$ decreases from $2.28 \%$ to $0.86 \%$ (Figure 7, Table 1) compared withthose of NWs+a single layer of NPs. This is due to the double and triple layer of nanoparticles on the top of nanowires, because most of the nanoparticles are sitting on the top of nanowireswithout any infiltration, where the resulting nanoparticle-nanowire contact area is minimized. It is worth noting that nanoparticle-nanowire and nanoparticle-nanoparticle contact areas are also important [27]. From Figure 4, the interface between two phases can be seen clearly, and the nanoparticles do not fill the interstitial voids after coating double and triple layers. The morphology obtained from double and triple coating layers-the thick layers of nanoparticles-forms a bottleneck to electron transport, because all the current from a thick layer of nanoparticles must pass through the nanowires to reach the electrode. Moreover, this thick layer also causes higher electron transport resistance and increases the recombination of electron with $I_{3}^{-}$on the $\mathrm{ZnO}$ surface, resulting in smaller $V_{\mathrm{oc}}$ and $\eta$ values. The cells fabricated from double and triple layers of NP photoelectrodes have shown low efficiency compared with their NWs/NWs+a single layer of NPs-based DSSCs counterparts. This decrease in $\eta$ is due to the following reasons.First, electron transfer from NP thick-layer electrodes is proposed to occur by a series of hopping events, which shows charge recombination and a non-exponential current, thereby slowing down excellent charge transport [31]. Second, the transport of electrons in the NPs film undergoes multiple trapping and detrapping processes. In addition, grain boundaries and mid gap states increased because of the thicker layers of NPs on the top of NWs, which results in a slow electron transport rate [49]. Third, an obvious drawback of the use of a double or triple layer of NPs on the top of NWs is that the thickness increases, whereas an overly thick film aggravates unwanted charge recombination and poses more constraints on mass transfer [33,34]. Thus, from the above discussion, we can infer that the appropriate content of NPs incorporation onto the NWs can promote the dye adsorption, transport the electrons, decrease the recombination of charge, and thereby increase the cells' performance.

Table 1. Parameters of $\mathrm{ZnO}$ nanostructured-based dye-sensitized solar cells (DSSCs).

\begin{tabular}{ccccc}
\hline Samples & $\begin{array}{c}\text { Short-Circuit Photocurrent } \\
\text { Density } J_{\mathbf{s c}}\left(\mathbf{m A} / \mathbf{c m}^{\mathbf{2}}\right)\end{array}$ & $\begin{array}{c}\text { Open-Circuit } \\
\text { Voltage } V_{\mathbf{~ o c}}(\mathbf{V})\end{array}$ & Fill Factor (FF) & $\eta(\mathbf{\%})$ \\
\hline NWs & $2.64 \pm 0.021$ & $0.72 \pm 0.020$ & $0.74 \pm 0.025$ & $1.43 \pm 0.015$ \\
NWs + single of NPs & $3.02 \pm 0.010$ & $0.74 \pm 0.015$ & $0.76 \pm 0.020$ & $2.28 \pm 0.011$ \\
NWs + double of NPs & $2.22 \pm 0.005$ & $0.69 \pm 0.012$ & $0.62 \pm 0.005$ & $0.93 \pm 0.017$ \\
NWs + triple of NPs & $2.11 \pm 0.011$ & $0.68 \pm 0.010$ & $0.58 \pm 0.005$ & $0.86 \pm 0.001$ \\
\hline
\end{tabular}

Table 2. Comparison of performance parameters of DSSCs.

\begin{tabular}{|c|c|c|c|c|}
\hline Samples & $\begin{array}{l}\text { Short-Circuit Photocurrent } \\
\text { Density } J_{\text {sc }}\left(\mathrm{mA} / \mathrm{cm}^{2}\right)\end{array}$ & $\begin{array}{c}\text { Open-Circuit } \\
\text { Voltage } V_{\text {oc }}(V)\end{array}$ & Fill Factor (FF) & $\eta(\%)$ \\
\hline ZnO NW-NP hybrid cell [27] & 3.00 & 0.77 & 0.65 & 1.3 \\
\hline $\mathrm{ZnO} \mathrm{NW}[44]$ & 2.5 & 0.44 & 0.47 & 0.45 \\
\hline ZnO NW-NP composite [44] & 8.33 & 0.58 & 0.58 & 2.77 \\
\hline $\mathrm{ZnO} \mathrm{NW}[45]$ & 4.55 & 0.60 & 0.41 & 1.16 \\
\hline ZnO NW-NP hybrid cell [45] & 15.16 & 0.61 & 0.46 & 4.24 \\
\hline $\mathrm{ZnO} \mathrm{NW}[46]$ & 2.52 & 0.53 & 0.37 & 0.49 \\
\hline ZnO NW-NP hierarchical [46] & 5.4 & 0.62 & 0.60 & 2.03 \\
\hline ZnO NR-NP hybrid cell [47] & 5.39 & 0.52 & 0.57 & 1.6 \\
\hline ZnO NR-NP hybrid cell [48] & 4.57 & 0.45 & 0.34 & 0.69 \\
\hline
\end{tabular}




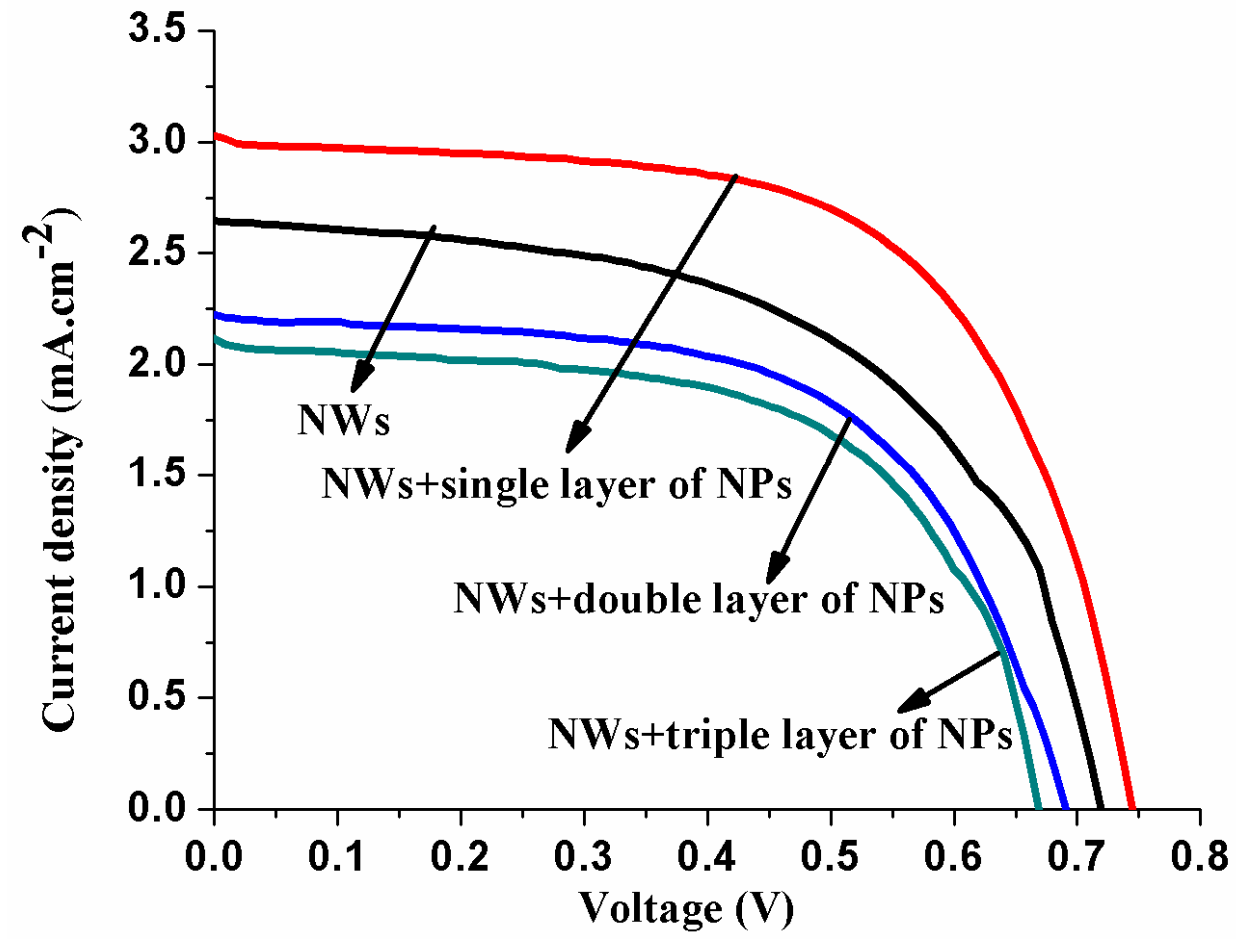

Figure 7. $J-V$ characteristics for $\mathrm{ZnO}$ compound nanostructures.

\section{Conclusions}

In summary, $\mathrm{ZnO}$ NWs and compound nanostructures of $\mathrm{ZnO}$ NWs+NPs with different coating layers of NPs on top of NWs were fabricated for the application of DSSCs. The transportation of electrons is high in compound nanostructures (NWs + NPs), and ZnO NPs filling the gaps between the $\mathrm{ZnO}$ NWs offers a high internal surface area for loading the dye and lightharvesting. The overall maximum efficiency of $2.28 \%$ for NWs+a single layer of NPs-based DSSCs was achieved with FF, $V_{\mathrm{OC}}, J_{\mathrm{SC}}$ values of $0.76,0.74 \mathrm{~V}$, and $3.02 \mathrm{~mA} / \mathrm{cm}^{2}$, respectively, which is $165 \%$ higher than that of their other counterparts. The improved performance was obtained due to the large surface area and light harvesting of compound nanostructures.

Author Contributions: Conceptualization, M.S.; methodology, W.A.F.; formal analysis, N.A.; investigation, M.N.A.; resources, S.U.R.; writing-original draft preparation, M.S. and M.I.K.; writing-review and editing, M.K., M.A. and M.I.; project administration, W.A.F.; funding acquisition, M.A.A.

Funding: The authors would like to extend their sincere appreciation to the Deanship of Scientific Research at King Saud University for its funding of this research through the Research Group Project no. RG-1435-059.

Conflicts of Interest: The authors declare no conflict of interest.

\section{References}

1. O'Regan, B.; Grätzel, M. A low-cost, high-efficiency solar cell based on dye-sensitized colloidal $\mathrm{TiO}_{2}$ films. Nature 1991, 353, 353-737. [CrossRef]

2. Grätzel, M. Photoelectrochemical cells. Nature 2001, 414, 338-344. [CrossRef] [PubMed]

3. Liu, J.; Cao, G.Z.; Yang, Z.; Wang, D.; Dubois, D.; Zhou, X.; Graff, G.L.; Pederson, L.R.; Zhang, J.-G. Oriented nanostructures for energy conversion and storage. Chem. Sus. Chem. 2008, 1, 258-265. [CrossRef] [PubMed]

4. Goetzberger, A.; Hebling, C. Photovoltaic materials, past, present, future. Sol. Energy Mater. Sol. Cells 2000, 62, 13546-13551. [CrossRef]

5. Goetzberger, A.; Hebling, C.; Schock, H.W. Photovoltaic materials, history, status and outlook. Mater. Sci. Eng. R Rep. 2003, 1, 40-46. [CrossRef]

6. Bagnall, D.M.; Boreland, M. Photovoltaic technologies. Energy Pol. 2008, 36, 4390-4396. [CrossRef]

7. Green, M.A. Recent developments in photovoltaics. Sol. Energy 2004, 76, 3-8. [CrossRef] 
8. Oliver, M.; Jackson, T. The market for solar photovoltaics. Energy Pol. 1999, 27, 371-385. [CrossRef]

9. Lieber, C.M.; Wang, Z.L. Functional nanowires. MRS Bull. 2007, 32, 99-108. [CrossRef]

10. Sattler, K. Handbook of Nanophysics: Nanotubes and Nanowires; CRC: Boca Raton, FL, USA, 2011.

11. Wang, Z. Nanowires and Nanobelts: Materials Properties and Devices: Volume 2: Nanowires and Nanobelts of Functional Materials; Springer: Berlin, Germany, 2005.

12. Pan, Z.W.; Dai, Z.R.; Wang, Z.L. Nanobelts of semiconducting oxides. Science 2001, 291, 1947-1949. [CrossRef]

13. Wang, Z. Oxide nanobelts and nanowires-growth, properties and applications. J. Nanosci. Nanotechnol. 2008, 8, 27-55. [CrossRef] [PubMed]

14. Feldheim, D.; Foss, C. Metal Nanoparticles: Synthesis, Characterization and Applications; CRC: Boca Raton, FL, USA, 2002.

15. Sugimoto, T. Fine Particles: Synthesis, Characterization and Mechanisms of Growth; CRC: Boca Raton, FL, USA, 2000.

16. Grätzel, M. Sol-gel processed $\mathrm{TiO}_{2}$ films for photovoltaic applications. J. Sol-Gel Sci. Technol. 2001, 22, 7-13. [CrossRef]

17. Saito, R.; Dresselhaus, G.; Dresselhaus, M. Physical Properties of Carbon Nanotubes; Imperial College Press: London, UK, 1999.

18. Baughman, R.H.; Zakhidov, A.A.; de Heer, W.A. Carbon nanotubes-the route toward applications. Science 2002, 297, 787-792. [CrossRef] [PubMed]

19. Grätzel, M. Solar energy conversion by dye-sensitized photovoltaic cells. Inorg. Chem. 2005, 44, 6841-6851. [CrossRef] [PubMed]

20. Law, M.; Greene, L.E.; Johnson, J.C.; Saykally, R.; Yang, P.D. Nanowire dye-sensitized solar cells. Nat. Mater. 2005, 4, 455-459. [CrossRef] [PubMed]

21. Baxter, J.B.; Aydil, E.S. Nanowire-based dye-sensitized solar cells. Appl. Phys. Lett. 2005, 86, $053114-053117$. [CrossRef]

22. Paulose, M.; Shankar, K.; Varghese, O.K.; Mor, G.K.; Grimes, C.A. Application of highly-ordered $\mathrm{TiO}_{2}$ nanotube-arrays in heterojunction dye-sensitized solar cells. J. Phys. D 2006, 39, 2498-2503. [CrossRef]

23. Wang, H.; Yip, C.T.; Cheung, K.Y.; Djurisic, A.B.; Xie, M.H.; Leung, Y.H.; Chan, W.K. Titania-nanotube-array-based photovoltaic cells. Appl. Phys. Lett. 2006, 89, 023508-023510. [CrossRef]

24. Jiang, C.Y.; Sun, X.W.; Lo, G.Q.; Kwong, D.L.; Wang, J.X. Improved dye-sensitized solar cells with a ZnO-nanoflower photoanode. Appl. Phys. Lett. 2007, 90, 263501-263503. [CrossRef]

25. Cheng, H.M.; Chiu, W.H.; Lee, C.H.; Tsai, S.Y.; Hsieh, W.F. Formation of branched ZnO nanowires from solvothermal method and dye-sensitized solar cells applications. J. Phys. Chem. C 2008, 112, 16359-16364. [CrossRef]

26. Chen, W.; Zhang, H.; Hsing, I.M.; Yang, S. A new photoanode architecture of dye sensitized solar cell based on $\mathrm{ZnO}$ nanotetrapods with no need for calcination. Electrochem. Commun. 2009, 11, 1057-1060. [CrossRef]

27. Baxter, J.B.; Aydil, E.S. Dye-sensitized solar cells based on semiconductor morphologies with $\mathrm{ZnO}$ nanowires. Energy Mater. Sol. Cells 2006, 90, 607-622. [CrossRef]

28. $\mathrm{Ku}, \mathrm{C} . \mathrm{H} . ; \mathrm{Wu}$, J.J. Electron transport properties in $\mathrm{ZnO}$ nanowire array/noparticle composite dye-sensitized solar cells. Appl. Phys. Lett. 2007, 91, 093117. [CrossRef]

29. $\mathrm{Ku}, \mathrm{C} . \mathrm{H} . ; \mathrm{Wu}$, J.J. Dye-sensitized solar cells based on nanoparticle-decorated $\mathrm{ZnO} / \mathrm{TiO} 2$ core/shell nanorod arrays. Appl. Phys. Lett. 2007, 91, 093117-093123.

30. Law, M.; Greene, L.E.; Radenovic, A.; Kuykendall TLiphardt, J.; Yang, P.D. $\mathrm{ZnO}-\mathrm{Al}_{2} \mathrm{O}_{3}$ and $\mathrm{ZnO}-\mathrm{TiO} 2$ Core-Shell Nanowire Dye-Sensitized Solar Cell. J. Phys. Chem. B 2006, 110, 22652. [CrossRef]

31. Saleem, M.; Fang, L.; Ahmad, M.A.; Raza, R.; Wu, F.; Li, W.J.; Xu, C.L.; Hu, L.; Xue, S.J. Synthesis, Characteristic and Appliction of $\mathrm{ZnO}$ Nanowires in dye-sensitized solar cells via Water Bath method. Nano 2014, 9, 1450061-1450068. [CrossRef]

32. Saleem, M.; Fang, L.; Shaukat, S.F.; Ahmad, M.A.; Raza, R.; Akhtar, M.N.; Jamil, A.; Aslam, S.; Abbas, G. Structural and photovoltaic characteristics of hierarchical ZnO nanostructures electrodes. Appl. Surf. Sci. 2015, 334, 145-150. [CrossRef]

33. Wang, Z.S.; Kawauchi, H.; Kashima, T.; Arakawa, H. Significant influence of $\mathrm{TiO}_{2}$ photoelectrode morphology on the energy conversion efficiency of N719 dye-sensitized solar cell. Coord. Chem. Rev. 2004, 248, 1381-1389. [CrossRef] 
34. Tan, B.; Wu, Y.Y. Dye-sensitized solar cells based on anatase $\mathrm{TiO}_{2}$ nanoparticle/nanowire composites. J. Phys. Chem. B 2006, 110, 15932-15938. [CrossRef]

35. Lee, B.; Hwang, D.K.; Guo, P.; Ho, S.T.; Buchholtz, D.B.; Wang, C.Y.; Chang, R.P.H. Materials, interfaces, and photon confinement in dye-sensitized solar cells. J. Phys. Chem. B 2010, 114, 14582-14591. [CrossRef]

36. Hsu, C.P.; Lee, K.M.; Huang, J.T.W.; Lin, C.Y.; Lee, C.H.; Wang, L.P.; Tsai, S.Y.; Ho, K.C. EIS analysis on low temperature fabrication of $\mathrm{TiO}_{2}$ porous films for dyesensitized solar cells. Electrochim. Acta 2008, 53, 7514-7522. [CrossRef]

37. Suri, P.; Mehra, R.M. Effect of electrolytes on the photovoltaic performance of a hybrid dye sensitized $\mathrm{ZnO}$ solar cell. Sol. Energy Mater. Sol. Cells 2007, 91, 518-524. [CrossRef]

38. Sheng, X.; Zhao, Y.; Zhai, J.; Jiang, L.; Zhu, D. Electro-hydrodynamic fabrication of ZnO-based dye sensitized solar cells. Appl. Phys. A 2007, 87, 715-719. [CrossRef]

39. Wang, Y.; Sun, Y.; Li, K. Dye-sensitized solar cells based on oriented $\mathrm{ZnO}$ nanowire-covered $\mathrm{TiO}_{2}$ nanoparticle composite film electrodes. Mater. Lett. 2009, 63, 1102-1104. [CrossRef]

40. Pasquier, A.D.; Chen, H.; Lu, Y. Dye sensitized solar cells using well-aligned zinc oxide nanotip arrays. Appl. Phys. Lett. 2006, 89, 253513-253515. [CrossRef]

41. Baxter, J.B.; Walker, A.M.; van Ommering, K.; Aydil, E.S. Synthesis and characterization of ZnO nanowires and their integration into dye-sensitized solar cells. Nanotechnology 2006, 17, S304-S312. [CrossRef]

42. Gao, H.; Fang, G.; Wang, M.; Liu, N.; Yuan, L.; Li, C.; Ai, L.; Zhang, J.; Zhou, C.; Wu, S.; et al. The effect of growth conditions on the properties of $\mathrm{ZnO}$ nanorod dye-sensitized solar cells. Mater. Res. Bull. 2008, 43, 3345-3351. [CrossRef]

43. Zhu, Y.F.; Shen, W.Z. Synthesis of ZnO compound nanostructures via a chemical route for photovoltaic applications. Appl. Phys. Lett. 2010, 256, 7472-7476. [CrossRef]

44. $\mathrm{Ku}, \mathrm{C} . \mathrm{H} . ; \mathrm{Wu}$, J.J. Chemical bath deposition of $\mathrm{ZnO}$ nanowire-nanoparticle composite electrodes for use in dye-sensitized solar cells. Nanotechnology 2007, 18, 505706. [CrossRef]

45. Yodyingyong, S.; Zhang, Q.; Park, K.; Dandeneau, C.S.; Zhou, X.; Triampo, D.; Cao, G. ZnO nanoparticles and nanowire array hybrid photoanodes for dye-sensitized solar cells. Appl. Phys. Lett. 2010, 96, 073115. [CrossRef]

46. Victoire-Marie, G.; Thierry, P. From nanowires to hierarchical structures of template-free electrodeposited $\mathrm{ZnO}$ for efficient dye-sensitized solar cells. Energy Environ. Sci. 2011, 4, 297.

47. Haller, S.; Suguira, T.; Lincot, D.; Yoshida, T. Design of a hierarchical structure of ZnO by electrochemistry for ZnO-based dye-sensitized solar cells. Phys. Status Solidi A 2010, 207, 2252-2257. [CrossRef]

48. Urgessa, Z.N.; Ruessa, R.; Djiokap, S.R.T.; Botha, J.R.; Schlettwein, D. Effect of morphology and surface treatment on the performance of $\mathrm{ZnO}$ nanorod-based dye-sensitized solar cells. J. Alloys Compd. 2019, 798, 249-256. [CrossRef]

49. Kopidakis, N.; Schiff, E.A.; Park, N.G.; van de Lagemaat, J.; Frank, A.J. Ambipolar Diffusion of Photocarriers in Electrolyte-Filled, Nanoporous $\mathrm{TiO}_{2}$. J. Phys. Chem. B 2000, 104, 3930-3936. [CrossRef] 